\title{
Cellulase Production from Penicillium citrinum using Brewer's Spent Grain and Pineapple Peels as Cheap, Alternate Substrates
}

\section{Olaoluwa Oyedeji1 ${ }^{\prime}$, Opeyemi O. Ojekunle ${ }^{1}$}

\author{
${ }^{1}$ Department of Microbiology, Faculty of Science, Obafemi Awolowo University, Ile-Ife, Nigeria
}

\begin{abstract}
Cellulases are major group of enzymes with wide-ranging industrial and biotechnological applications. The high cost of cellulase production is a major factor limiting its industrial applications in cellulose bioconversions, hence the need to develop low-cost production systems for this enzyme. Cellulose-rich plant biomass which may be agricultural or industrial in origin exists abundantly as organic wastes which are detrimental to the environment. This study evaluated cellulase production by Penicillium citrinum isolated from deteriorating orange fruits, using brewer's spent grain and pineapple peels as cheap, alternate substrates. Cellulase titres $3.82 \pm 0.136 \mathrm{U} / \mathrm{mL}$ and 1.405 $\pm 0.151 \mathrm{U} / \mathrm{mL}$ were produced by the fungus, using pineapple peels and brewer's spent grain as substrates, respectively, under submerged fermentation. Maximum cellulase production by $P$. citrinum occurred with the use of pineapple peels as substrate, after $72 \mathrm{~h}$ fermentation period, with the use of pineapple peels at a concentration of $1.5 \% \mathrm{w} / \mathrm{v}$ and peptone as the best nitrogen source. The optima $\mathrm{pH}$ and temperature for the production of cellulase by the fungus was found to be 6.0 and $50{ }^{\circ} \mathrm{C}$, respectively. Findings from this study indicated the potential use of pineapple peels as cheaper, alternative substrate for the production of cellulase thus mitigating its hazardous effect on the environment as pollutant. $P$. citrinum was able to grow and produce good levels of cellulase using solely pineapple peels as low-cost substrate, at high temperature of $50{ }^{\circ} \mathrm{C}$, making this strain and this low-cost agroindustrial residue worthy of further investigation and potentially feasible for a wide range of biotechnological applications.
\end{abstract}

Keywords: Cellulase, Cellulose, Penicillium citrinum, Agro-Industrial Wastes, Brewer's Spent Grain, Pineapple Peels

\section{Introduction}

Cellulose is the most abundant biopolymer in nature constituting the major component of plant cell wall, followed by hemicelluloses and lignin (Lynd et al., 2002; Han et al., 2003; Cosgrove, 2005). Cellulose is a linear polysaccharide polymer with many Dglucose units linked by $\beta$-1,4-glycosidic bonds (Hikaru et al., 2008). It has a crystalline structure stabilized by intramolecular and intermolecular hydrogen bonds (Hikaru et al., 2008). Cellulose-rich plant biomass exists abundantly as organic wastes which are detrimental to the environment. This abundant biomass, which may be agricultural, urban or industrial in origin, could be utilized more efficiently by being converted to fermentable sugars which act as carbon source for the production of various products of commercial interests such as fuels and chemicals (Chen et al., 2007). The natural degradation of cellulose is carried out by cellulolytic microorganisms, which form an important part of the biosphere carbon cycle. Complete hydrolysis of cellulose to glucose is carried out by the synergistic action of three cellulolytic enzyme system (Bakare et al., 2005; Eveleigh et al., 2005; Gautam et al., 2010). $\beta$-1,4-endoglucanase [EC3.2.1.4] randomly attacks the internal glycosidic bonds, resulting in glucan chains of different lengths; the $\beta$-1,4-exoglucanase [EC3.2.1.91] acts on the ends of the cellulose chain and releases $\beta$-cellobiose as the end products while the $\beta$-glucosidases acts specifically on the $\beta$ cellobiose by hydrolysis giving rise to two glucose molecules (Singh, 1999; Sarao et al., 2010; Akinyele et al., 2013). Cellulases have numerous applications and biotechnological potentials for various industries including chemicals, fuels, food, brewery, animal feed, textile, pulp and paper industries (Bhat, 2000; Ogel et al., 2001; Abo-State et al., 2010).

The cost of cellulase production remains a key issue in the bioconversion of cellulose-rich plant biomass

This article is published under the terms of the Creative Commons Attribution License 4.0

Author(s) retain the copyright of this article. Publication rights with Alkhaer Publications.

Published at: http://www.ijsciences.com/pub/issue/2018-01/

DOI: 10.18483/ijSci.1513; Online ISSN: 2305-3925; Print ISSN: 2410-4477 
for the production of cellulosic ethanol (Fang et al., 2009; Brijwani et al., 2010). Significant efforts are thus required towards lowering the contribution of enzymes to biofuel production costs (Blanch et al., 2011). Organic wastes from agricultural and industrial residues, which otherwise constitute environmental pollution, are renewable sources of substrates which can be utilized for cellulase production by microorganisms. Various agricultural wastes such as wheat straw, soybean hull, corn stove, wheat bran, dairy manure and bagasse have been used for the production of enzymes (Brijwani et al., 2010).

Brewer's spent grain (BSG) is a by-product of the brewery industry, being the barley malt residue obtained after wort elaboration. It consists primarily of grain husk and other residual compounds not converted to fermentable sugars by the mashing process (Xiros et al., 2008). The cellulose content ranges between $9 \%$ and $25 \%$ per dry matter. The chemical composition of $\mathrm{BSG}$ varies according to barley variety, harvest time, malting and mashing conditions, and quality and type of adjuncts added in the brewing process. Although part of it is used as animal feed, it is still largely available, being an interesting source as raw material for the production of variety of products including lactic acid (Mussato et al., 2008), breads (Stojceska and Ainsworth, 2008), and enzymes such as cellulases and hemicellulases for bioethanol production (Mussato et al., 2008).

Pineapple peels is a by-product of the pineapple juice-processing industry. Its production in large quantities results in serious waste disposal problem which can lead to environmental pollution, if not utilized (Rani and Nand, 2004). Finding use, especially on a large scale, for this abundant waste material would therefore be profitable from both an environmental and economic point of view. The peel is rich in cellulose, hemicelluloses and other carbohydrates. It has a substrate potential generation of methane by anaerobic digestion and currently has limited use as animal, poultry and fish feeds (Rani and Nand, 2004; Paengkoum et al., 2013).

In this study, cellulases were produced by a strain of $P$. citrinum isolated from deteriorating orange fruits using brewer's spent grain and pineapple peels as substrates. The influence of several cultural factors such as carbon sources (substrate), nitrogen sources, fermentation period, $\mathrm{pH}$ and temperature, on cellulase production, was then investigated.

\section{Materials and methods}

\section{Isolation of fungi}

Orange fruits, at different stages of decay, were collected from the fruits market in Ile-Ife, Nigeria, using sealed cellophane bags and transported to the laboratory of the Department of Microbiology, Obafemi Awolowo University, Ile-Ife where fungal isolations were carried out immediately. A sterilized scalpel was used to cut deeply into decayed portions of the orange fruits and sterile inoculating needle was used to collect samples which were placed on the surface of freshly prepared and sterilized malt extract agar in Petri dishes. The culture plates were then incubated at $26{ }^{\circ} \mathrm{C}$ for 4-6 days. Morphologically distinct fungal growths were subcultured onto fresh plates of malt extract agar until pure isolates were obtained. Pure fungi were then maintained on potato dextrose agar (PDA) slants at $4^{\circ} \mathrm{C}$ inside the refrigerator.

\section{Characterization and identification of fungi}

The fungal isolates were characterized and identified by observing their macroscopic morphological features such as surface colour on plates, texture, appearance, bottom of plates colour and diameter of colonies. The microscopic morphological characteristics observed were the spore type and shape, type of sporangia and type of hyphae. Smears of the isolated fungi were prepared with dissecting needle in lactophenol cotton blue stain on a glass slide, covered with cover slip and examined with $\mathrm{x}$ 40 objective of a compound binocular microscope (Barnett and Hunter, 1972; Domsch et al., 1986; Benson, 1990; Lieckfield et al., 1999). Four fungal isolates - Aspergillus malignus, Aspergillus terreus, Fusarium solani and Penicillium citrinum were isolated from deteriorating orange fruits collected from the fruits market in Ile-Ife, Nigeria.

\section{Screening of fungi for cellulase production}

The four fungal isolates were screened for their cellulolytic activities on carboxymethyl cellulose, as sole carbon source, under submerged fermentation condition.

\section{Preparation of agro-industrial wastes}

The agro-industrial wastes brewer's spent grain (Hordeum vulgare) and pineapple peel (Ananas comosus) were obtained locally from their dumpsites. The residues were prepared by exhaustive washing with distilled water, followed by drying at $70{ }^{\circ} \mathrm{C}$ in an oven for $2 \mathrm{~h}$. They were then milled, sieved at $40 \mathrm{~mm}$ mesh size and stored in airtight transparent plastic containers to keep them moisture-free (Hafiz et al., 2010). The substrates were treated to autoclaving for $1 \mathrm{~h}$ with $5 \% \mathrm{w} / \mathrm{v} \mathrm{NaOH}(20 \mathrm{~mL}$ per gram of substrate) in flasks for delignification. They were then washed thoroughly with distilled water and neutralized with 1 
$\mathrm{M} \mathrm{HCl}$. They were finally washed with distilled water and dried (Ali et al., 1991).

\section{Submerged fermentation and extraction of enzyme \\ Medium composition used for submerged} fermentation (in $\mathrm{g} / \mathrm{L}$ ), according to the modified method of Mandels and Weber (1969), were $\mathrm{K}_{2} \mathrm{HPO}_{4}, \quad 0.5 ; \quad \mathrm{KH}_{2} \mathrm{PO}_{4}, \quad 2.0 ; \quad \mathrm{KNO}_{3}, \quad 9.9 ;$ $\mathrm{MgSO}_{4} .7 \mathrm{H}_{2} \mathrm{O}, 0.1 ; \mathrm{FeSO}_{4} .7 \mathrm{H}_{2} \mathrm{O}, 0.1 ; \mathrm{MnSO}_{4} .7 \mathrm{H}_{2} \mathrm{O}$, $0.01 ; \mathrm{ZnSO}_{4} .7 \mathrm{H}_{2} \mathrm{O}, 0.01$, supplemented with brewer's spent grain $(5.0 \mathrm{~g} / \mathrm{L})$ or pineapple peels $(5.0 \mathrm{~g} / \mathrm{L})$. Fermentations were performed in $250 \mathrm{~mL}$ Erlenmeyer flasks containing $100 \mathrm{~mL}$ of the culture medium. Standardized spore suspensions of $P$. citrinum $\left(1 \times 10^{6}\right.$ spores $\left./ \mathrm{mL}\right)$ were used to inoculate $100 \mathrm{~mL}$ of pre-sterilized basal medium. The fermentation culture was incubated at $35^{\circ} \mathrm{C}$, under agitation on orbital shaker (180 rpm), for 5 days. After incubation, the whole content of the shake flasks were centrifuged at $5000 \mathrm{rpm}$ for $10 \mathrm{~min}$ at $4^{\circ} \mathrm{C}$ using the refrigerated ultracentrifuge. This was then filtered through glass microfiber filter (Whatman GF/A, UK) and the crude supernatant used for enzymatic assays. Experiments were carried out in duplicates and results were expressed as average values.

\section{Cellulase assay}

Carboxymethyl cellulase activity was determined by measuring the release of reducing sugar glucose in a reaction mixture of $1.0 \mathrm{ml}$ of the crude supernatant and $1.0 \mathrm{ml}$ of $2 \%\left({ }^{\mathrm{w}} / \mathrm{v}\right)$ carboxymethyl cellulose (CMC) sodium salt (Sigma, St Louis, MO, USA) solution in $0.05 \mathrm{M}$ citrate phosphate buffer $(\mathrm{pH} 4.5)$ incubated at $50^{\circ} \mathrm{C}$ for $30 \mathrm{~min}$. The control sample contained the same amount of substrate and $1.0 \mathrm{ml}$ of the enzyme solution heated at $100^{\circ} \mathrm{C}$ for $15 \mathrm{~min}$, incubated at same conditions. At the end of incubation period, the reaction was terminated by addition of $3.0 \mathrm{ml}$ of 3, 5-dinitrosalicylic acid (DNSA) reagent (Miller, 1959). Each tube was incubated for $5 \mathrm{~min}$ in a boiling water bath and then cooled rapidly. The cellulose activity of the reaction mixture was measured against a blank sample at wavelength of $540 \mathrm{~nm}$. The concentration of glucose released by enzyme was determined against a standard caliberation curve of glucose concentration. One unit (U) of carboxymethyl cellulase activity corresponded to $1.0 \mu \mathrm{mol}$ of glucose equivalent released per milliliter per min under the assay conditions according to Ghose (1987).

\section{Screening of agro-industrial residue as substrate} for cellulase production

Brewer's spent grain (BSG) and pineapple peels (PP) were each incorporated into the basal medium as sole carbon source in a concentration of $5.0 \mathrm{~g} / \mathrm{L}$ with $\mathrm{CMC}$ serving as control. Equal $5.0 \mathrm{~g} / \mathrm{L}$ concentration combinations of $\mathrm{CMC}$ and $\mathrm{BSG}$, and $\mathrm{CMC}$ and $\mathrm{PP}$ were also set up in flasks of basal medium. After inoculation with standardized spore suspension of $P$. citrinum, the flasks were incubated at $30{ }^{\circ} \mathrm{C}$ for 4 days at 120 days at $120 \mathrm{rpm}$ on a rotary shaker (Gautam et al., 2010). At the end of incubation, the culture supernatant was assayed for enzyme activity using the method stated above.

\section{Effect of varying substrate concentrations on} cellulase production

The effect of varying concentrations $(0.5$ to $3.0 \% \mathrm{w} / \mathrm{v})$ of selected substrate (pineapple peels) on cellulose production by $P$. citrinum was determined. After inoculation with standardized spore suspensions of the isolate, the flasks were incubated at $30{ }^{\circ} \mathrm{C}$ for 4 days at $120 \mathrm{rpm}$ on a rotary shaker (Gautam et al., 2010). At the end of incubation, the culture supernatants were assayed for enzyme activities using the method stated above.

Effect of nitrogen sources on cellulase production The effect of various nitrogen sources, at $5 \mathrm{~g} / \mathrm{L}$, on cellulase production was determined by supplementing the fermentative medium with various nitrogen sources (ammonium sulphate, glycine, peptone, urea, yeast extract). Fermentation was carried out at $35^{\circ} \mathrm{C}$ for 3 days in an orbital shaker incubator at $120 \mathrm{rpm}$. The cell-free supernatant obtained was assayed for cellulase activity and protein concentration as stated above.

\section{Effect of $\mathrm{pH}$ and temperature on cellulase production}

The effect of initial $\mathrm{pH}$ on cellulase production was determined by varying the $\mathrm{pH}$ values of the fermentation medium from 3.5 to 6.5 . The influence of temperature on cellulase production was also determined by varying the temperature of incubation from $30{ }^{\circ} \mathrm{C}$ to $60{ }^{\circ} \mathrm{C}$. Submerged fermentation was carried out for 3 days at $120 \mathrm{rpm}$ in an orbital shaker incubator. The cell-free supernatant obtained was assayed for cellulase activity as stated above.

\section{Effect of fermentation period on cellulase production}

The influence of fermentation periods, up to $120 \mathrm{~h}$, using optimal conditions established previously, was studied. The cellulase activities in fermentation media supplemented with pineapple peels as substrates were measured at $24 \mathrm{~h}$ intervals throughout the $120 \mathrm{~h}$ incubation period (Milala et al., 2005).

\section{Results}

Characterization and identification of fungal isolates

Cultural, morphological and microscopical observations made on all the isolates showed that 
Cellulase Production from Penicillium citrinum using Brewer's Spent Grain and Pineapple Peels as Cheap, Alternate Substrates

they were all fungi. Four morphologically-distinct fungal strains were obtained from the decayed orange fruits. Based on the phenotypic characterization of the isolates such as distinctive characters of the arrangement, shapes and sizes of macro- and microconidia, presence and absence of chlamydospores as well as colony appearances and pigmentations on potato dextrose agar medium, they were identified as Aspergillus malignus, Aspergillus terreus, Fusarium solani and Penicillium citrinum.

\section{Screening of fungal isolates for cellulase production}

The four fungal isolates - Aspergillus malignus, Aspergillus terreus, Fusarium solani and Penicillium citrinum screened for their ability for cellulase production on CMC as sole carbon source. $P$. citrinum exhibited the highest cellulase activity $(1.008 \pm 0.079 \mathrm{U} / \mathrm{mL})$ and was therefore selected for subsequent studies (Figure 1).

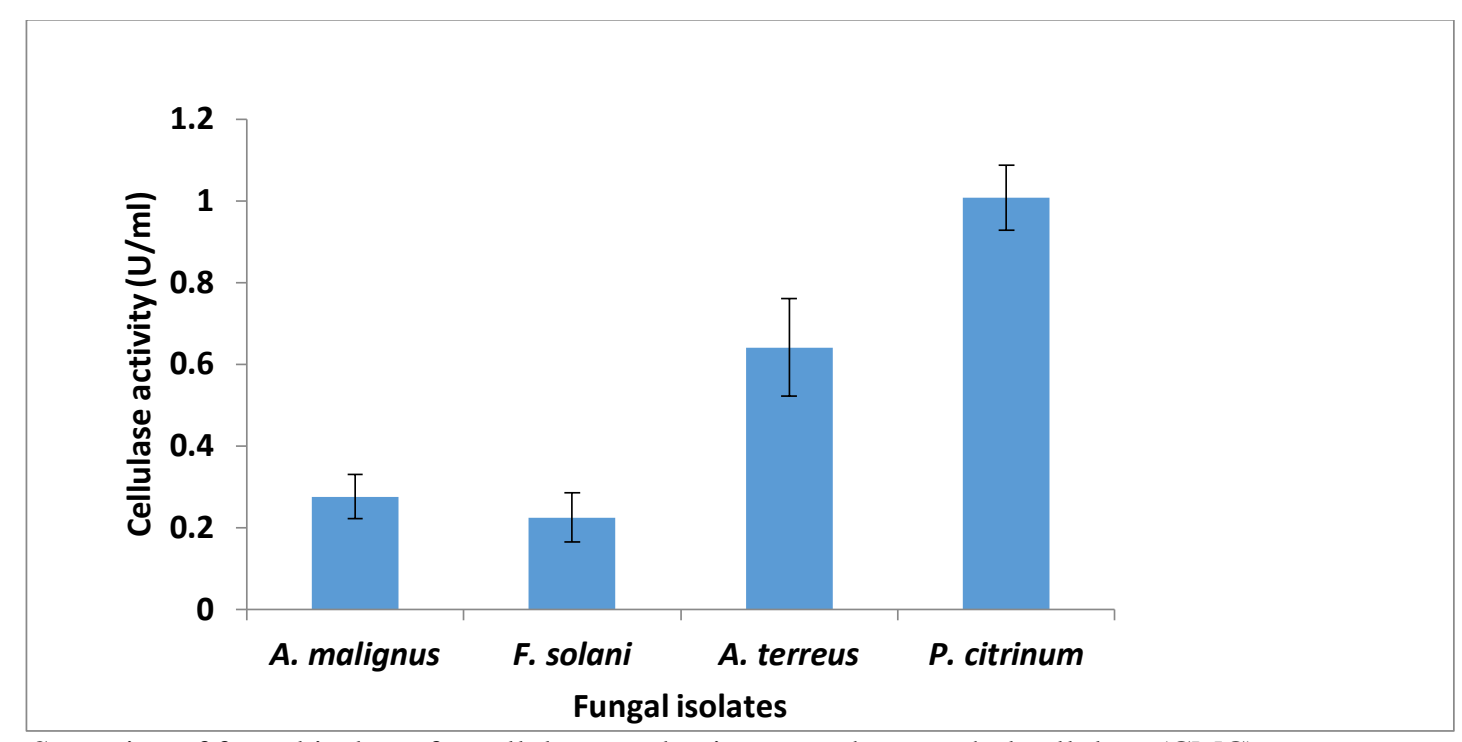

Fig 1. Screening of fungal isolates for cellulase production on carboxymethyl cellulose (CMC).

Effect of agro-industrial wastes, as substrates for cellulase production

$P$. citrinum utilized both BSG and PP as substrates for cellulase production but the maximum cellulase activity $(3.832 \pm 0.136 \mathrm{U} / \mathrm{mL})$ was observed with the use $5.0 \mathrm{~g} / \mathrm{L}$ pineapple peel as the sole carbon source
(Figure 2). The use of BSG as carbon source for cellulase production from the fungus produced enzyme activity of $1.405 \pm 0.151 \mathrm{U} / \mathrm{mL}$. The use of $\mathrm{PP}$ as substrate produce avtivitiy of $2.89 \pm 0.173$ $\mathrm{U} / \mathrm{mL}$ while combinations of CMC and BSG gave the enzyme activity of $1.188 \pm 0.074 \mathrm{U} / \mathrm{mL}$ (Figure 2 ).

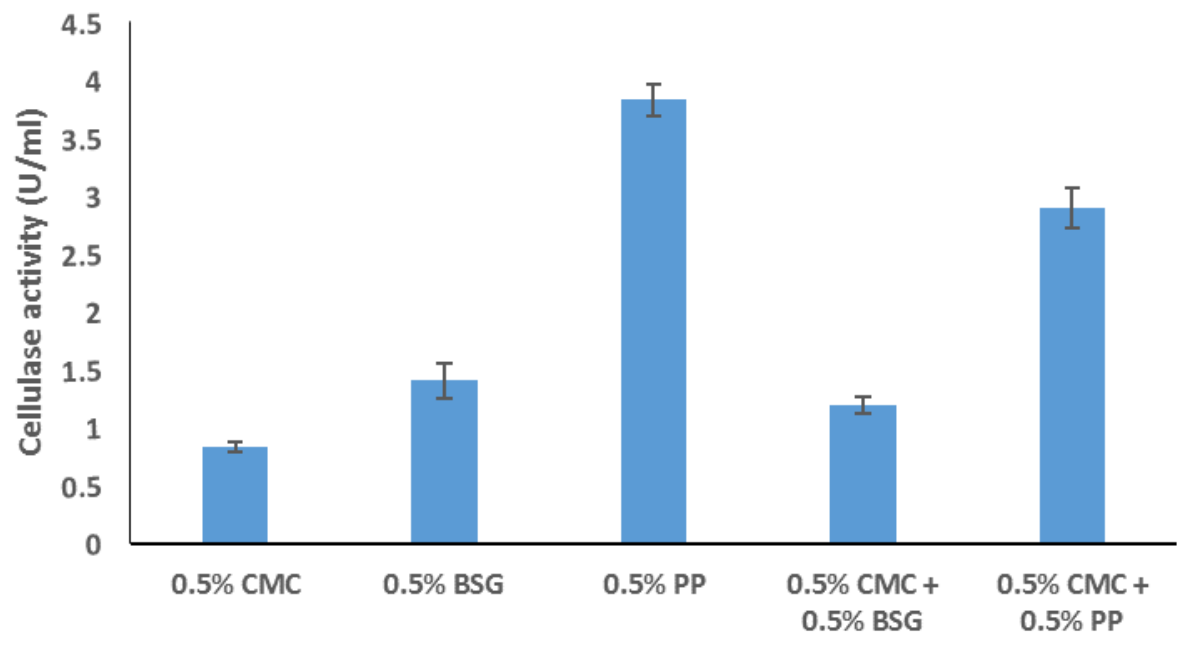

Carbon sources (Substrates) 
Fig. 2 Effect of different carbon sources on cellulase production by P. citrinum. CMC - carboxymethyl cellulose; BSG - brewer's spent grain; PP - pineapple peels.

Effect of substrate (pineapple peels) concentrations on cellulase production

Cellulase activity was studied by varying the concentrations of substrate/ pineapple peels incorporated into fermentation medium. Cellulase activity increased with pineapple peel concentration until it reached the maximum with the use of $1.5 \% \mathrm{w} / \mathrm{v}$ pineapple peel in the fermentation medium (Figure 3). Substrate concentrations beyond this led to gradual decrease in cellulase activity and hence production.

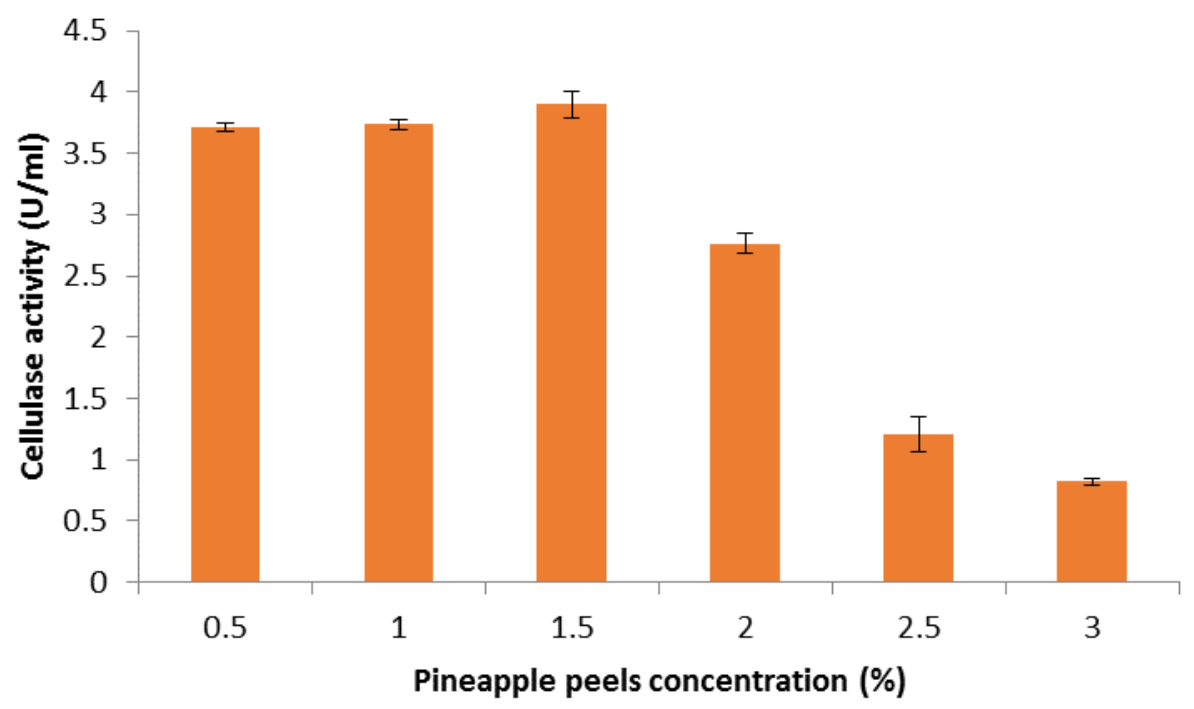

Fig. 3 Effect of varying concentrations of pineapple peels on cellulase production by P. citrinum.

Effect of nitrogen sources on cellulase production The effect of nitrogen sources on cellulase production from $P$. citrinum is presented in Figure 4. Among the nitrogen sources used, peptone produced the maximum enzyme production $(3.148 \pm 0.136 \mathrm{U} / \mathrm{mL})$ followed by the use of yeast extract $(2.084 \pm 0.187$ $\mathrm{U} / \mathrm{mL})$ and urea $(2.134 \pm 0.127 \mathrm{U} / \mathrm{mL})$ while the use of ammonium sulphate produced the least enzyme activity and hence production $(1.723 \pm 0.052 \mathrm{U} / \mathrm{mL})$ (Fig. 4).

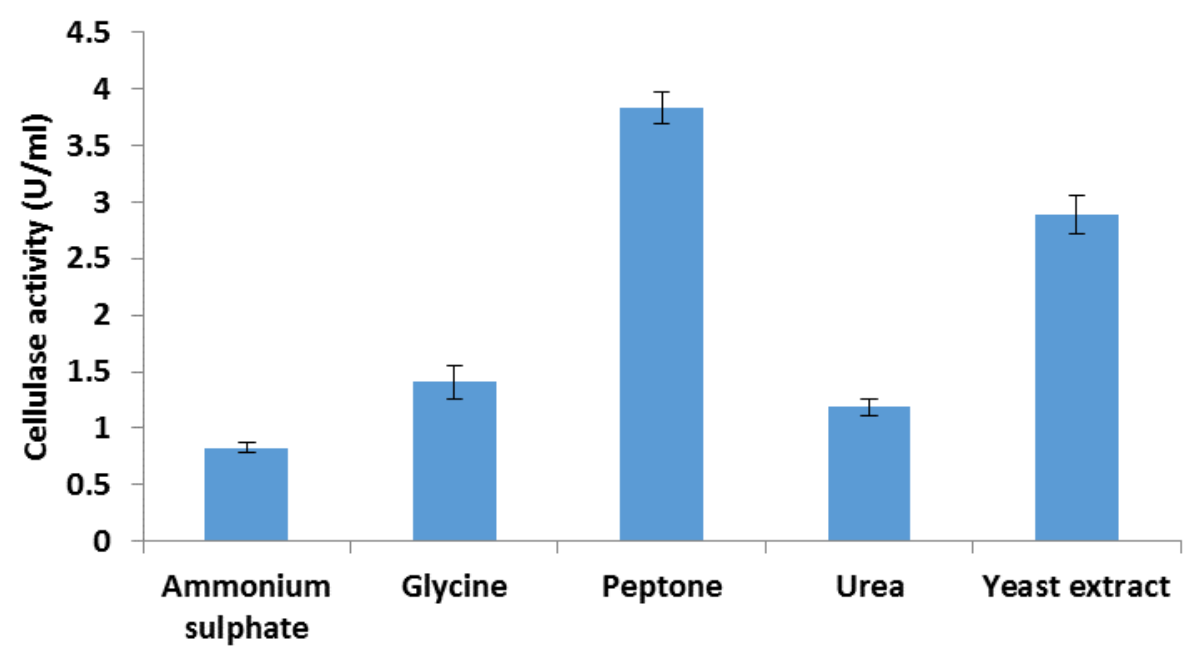

Nitrogen sources

Fig. 4 Effect of different nitrogen sources on cellulase production from P. citrinum using pineapple peels as sole carbon source. 


\section{Effect of $\mathrm{pH}$ and temperature on cellulase} production

The influence of $\mathrm{pH}$ on cellulase production from $P$. citrinum is presented in Figure 5. Cellulase activities increased with increasing $\mathrm{pH}$ untill it reached maximum at the $\mathrm{pH}$ value of $6.0(3.296 \pm 0.068$ $\mathrm{U} / \mathrm{mL}$. $\mathrm{pH}$ values above this resulted into steady decrease in cellulase activities.
The influence of temperature on the production of cellulase from $P$. citrinum, using pineapple peels as substrate, is presented in Figure 5. Maximum cellulase production was observed at $50{ }^{\circ} \mathrm{C}(3.202 \pm$ $0.122 \mathrm{U} / \mathrm{mL})$. Above this temperature, cellulase production decreased steadily (Figure 6).

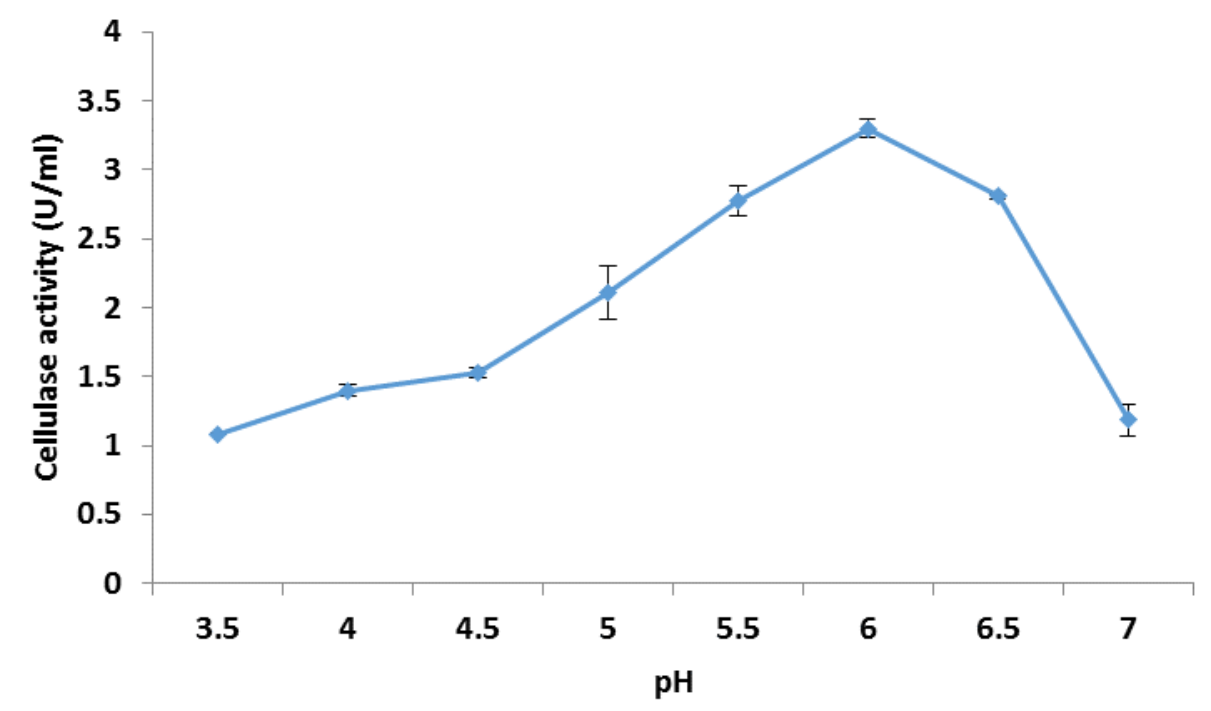

Fig. 5 Effect of $\mathrm{pH}$ on cellulase production by $P$. citrinum using pineapple peels as sole carbon source.

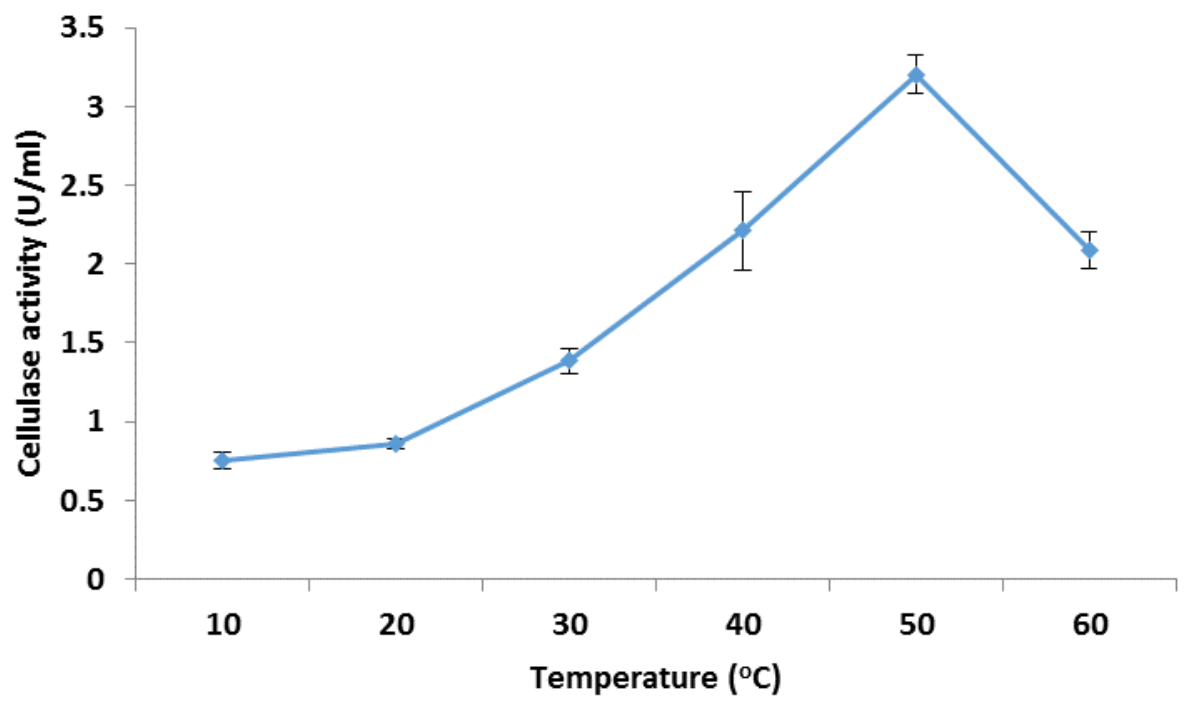

Fig. 6 Effect of temperature on cellulase production by $P$. citrinum pineapple peels as sole carbon source.

Effect of fermentation period on cellulase production

Fermentation time course profile showed considerable variation in cellulase production at different fermentation period. The cellulase production increased with fermentation period until it reached the maximum $(3.190 \pm 0.144 \mathrm{U} / \mathrm{mL})$ after 72 $\mathrm{h}$ incubation. Beyond this period, there was a steady decline in cellulase production (Figure 7). 


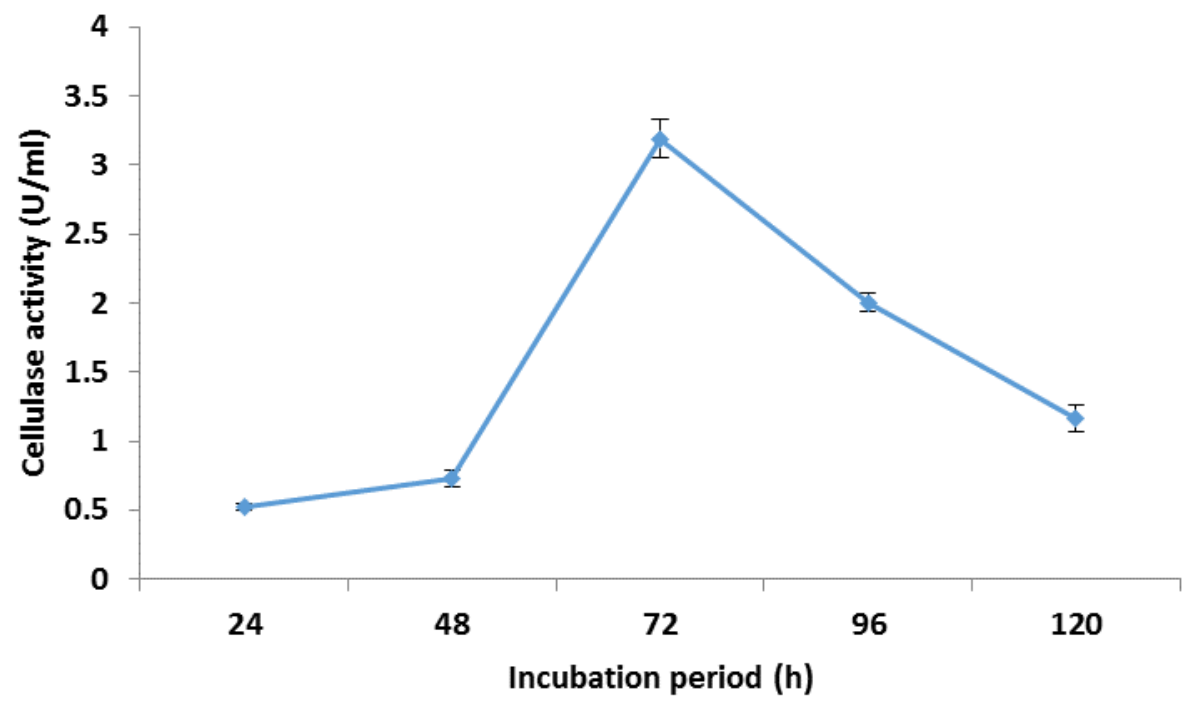

Fig. 7 Effect of incubation period on cellulase production from $P$. citrinum using pineapple peels as sole carbon source.

\begin{abstract}
Discussion
In the present study, Penicillium citrinum has been used to produce cellulase using low-cost, readily available agro-industrial residues such as brewer's spent grain and pineapple peels, which otherwise, mostly constituted pollution in the environment. Cellulases have wide applications with potentials for use in the food processing, detergent and textile industries as well as in the conversion of agricultural (lignocellulosic) biomass into products with commercial value (Bon and Ferrara, 2007; Asgher et al., 2013; Iqbal et al., 2013; Irshad et al., 2013). With the increasing demand for alternative liquid fuels worldwide, cellulase is also used as the primary enzyme for enzymatic hydrolysis of lignocellulosic biomass in bioethanol production process.
\end{abstract}

The production economics of bioethanol is largely dependent on the cost of cellulase. The high cost of cellulase presents a significant barrier to their use for these wide-ranging commercial applications hence economic ways of producing the enzyme has attracted worldwide attention (Fang et al., 2009; Brijwani et al., 2010; Klein-Marcuschamer et al., 2011). For enzyme production cost to be minimized, there has to be consistent and considerable progress made in strain development, optimization of culture conditions, mode of fermentation and modelling the process (Lee et al., 2005; Acharya and Chaudhury, 2012; Riswan et al., 2012).

Four fungal species, isolated from deteriorating orange fruits, were screened for their ability for cellulase production, on carboxymethyl cellulose, under submerged fermentation. All the isolates secreted cellulase into the medium with $P$. citrinum producing the highest concentration of cellulase. It was therefore selected for further studies. The difference in the amount of cellulase production from the different fungi may be attributed to differences in their genetic compositions (Gautam et al., 2010).

The capacity for the hydrolytic breakdown of lignocellulosic materials is distributed among certain species of bacteria, fungi and actinomycetes (Hafiz et al., 2010). Microorganisms are capable of utilizing the organic matter in wastes both as a source of energy for growth and as carbon source for the synthesis of cell biomass and essential molecules such as enzymes Kim and Dale, 2004). Cellulolytic activities were detected to different levels when $P$. citrinum was grown in fermentation media containing different agro-industrial wastes as substrates. Among the lignocellulosic wastes tested, pineapple peels (PP) was found to be the best substrate for cellulase production followed by brewer's spent grain (BSG), equal combination of $\mathrm{CMC}$ and $\mathrm{PP}$ and equal combination of CMC and BSG. Differences in the production of cellulolytic enzymes on a variety of lignocellulosic substrates by microorganisms could be due to factors such as variability in cellulose content and nature, substrate accessibility, presence of activators and inhibitors and natural cellulolytic abilities of the organism at different conditions Narasimha et al., 2006; Mabrouk and Ahwany, 2008). Several lignocellulosic wastes have been utilized as substrates for cellulase production by several researchers. These included sawdust (Narasimha et al., 2009), wheat bran (Chandra et al., 2007), brewer's spent grain (Nascimento et al., 
2009), rice bran (Reddy et al., 2015), pineapple pulp (Omojasola et al., 2008) and wheat straw (Azzaz et al., 2012). The use of lignocellulosic biomass for cellulase production has become a common trend in recent years since this significantly reduces costs (Adsul et al., 2004; Nascimento et al., 2009; Balaraju et al., 2010; Ravindran et al., 2010). Deposition or release of these wastes is one of the main causes of environmental pollution with the attendant health hazards. Microbial conversion into useful products such as enzymes may therefore serve to control the problems of environmental pollution. Agro-industrial wastes could be considered as promising low-cost raw materials as a result of their great availability in nature and renewable characteristics (Rubin, 2008).

A substrate concentration of $1.5 \% \mathrm{w} / \mathrm{v}(15.0 \mathrm{~g} / \mathrm{L})$ pineapple peel gave the highest yield of cellulase in the fermentation medium. Further increase in concentration led to sharp decline in cellulase yield. A $1.0 \%$ substrate concentration gave the highest yield of cellulase from Trichoderma longibrachiatum on pineapple pulp (Omojasola et al., 2008). Substrate concentration is an important factor in enzyme yield and substrate hydrolysis rate (Reddy et al., 2015). Increase in substrate concentration beyond the optimum can lead to saturation which substantially lowers enzyme formation (Liu and Yang, 2007).

Maximum cellulase production was observed after 72 $\mathrm{h}$ fermentation period, using pineapple peels as substrate. Beyond this period, enzyme production decreased drastically. The reduction in enzyme yield might be as a result of denaturation of enzyme resulting from variation in $\mathrm{pH}$ during fermentation according to Krishna (1999), or due to cumulative effect of cellobiose which is known to inhibit both endoglucanase and $\beta$-glucosidase (Howell and Mangat, 1978). Our results are in consistency with those reported by Chandra et al (2007), in which cellulase showed maximum activity after $72 \mathrm{~h}$ fermentation by A. niger on groundnut fodder, wheat bran and rice bran. Milala et al. (2005) also reported maximum cellulase activity after $72 \mathrm{~h}$ fermentation by $A$. niger grown on maize straw and rice husk. On the other hand, Nipa et al. (2006) and Akinyele et al. (2013) reported $96 \mathrm{~h}$ as the optimum fermentation period for cellulase production from A. humicola and A. niger, respectively. However, a short fermentation period for enzyme production offers potential for inexpensive production of enzyme (Sonjoy et al., 1995).

Optimum $\mathrm{pH}$ for cellulase production was found to be 6.0. As the $\mathrm{pH}$ level increased, enzyme production decreased. The initial $\mathrm{pH}$ of the medium has a great effect on microbial growth, permeability of membrane as well as on the biosynthesis and stability of the enzyme (Shoichi et al., 1985; Odeniyi et al.,
2009). The $\mathrm{pH}$ change observed during growth of microbes also affects product stability in the medium (Gupta et al., 2008). A similar observation was made for cellulase production from A. terreus Ali et al. (1991) and Azzaz et al. (2012). However, the best $\mathrm{pH}$ for celluase production from different strains of $A$. niger were observed to be 5.0 according to Pham et al. (2010) and 5.5 according to Akinyele et al. (2013).

In this study, the optimum temperature for cellulase production from $P$. citrinum was found to be $50{ }^{\circ} \mathrm{C}$. Maximum cellulase production was observed at 40 ${ }^{\circ} \mathrm{C}$ for A. terreus according to Ali et al. (1991) and $37^{\circ} \mathrm{C}$ for $P$. fellutanum according to Kathiresan and Manivannan (2006). Temperature of incubation plays important role in the metabolic activities of microorganisms and optimum temperature for cellulase production depends on strain variation of the microorganisms (Gautam et al., 2010).

Among the five nitrogen sources tested, peptone was found to be the best for producing cellulase from $P$. citrinum. Differences in cellulase production from the use of various nitrogen sources may be due to the fact that peptone may be readily available to the fungus for metabolism during growth and enzyme production as opposed to the others. Our result is in line with those of other workers (Devanathan et al., 2007; Mrudala and Murugammal, 2011). Organic nitrogen sources such as peptone were also found to be more suitable for optimizing cellulase production from Bacillus alkalophillus S39 and $B$. amyloliquefaciens $\mathrm{C} 28$ than the inorganic sources (Abou-Taleb et al., 2009). However, Xavier and Lonsane 1994) indicated that the source of nitrogen should be inorganic for better results. Differences in enzyme yields in different studies could be due to differences in cultural practices and different strains of organisms used (Chandra et al., 2007).

\section{Conclusions}

This study has revealed that Penicillium citrinum, isolated from deteriorating orange fruits, exhibited unique characteristics of thermostability and the ability to utilize pineapple peels as cheap substrate for the production of cellulase. The result obtained also indicated a biotechnological control of environmental pollution through microbial bioconversion of agro-industrial wastes into commercially valuable cellulases, with wide-ranging industrial applications. Optimal cultural factors for cellulase production from the fungus were a fermentation period of $72 \mathrm{~h}, 1.5 \% \mathrm{w} / \mathrm{v}$ pineapple peels concentration, optima $\mathrm{pH}$ and temperature of 6.0 and $50{ }^{\circ} \mathrm{C}$, respectively and $0.5 \% \mathrm{w} / \mathrm{v}$ peptone concentration as nitrogen source. 

Substrates

\section{Conflict of interest}

The authors declare no conflict of interest.

\section{References}

1. Abo-State, M.A.M., Hammad, A.I., Swelim, M. and Gannam, R.B (2010). Enhanced Production of Cellulases by Aspergillus spp isolated from Agricultural Wastes by Solid State Fermentation. American Eurasian Journal of Agriculture and Environmental Sciences, 8(4):402-410.

2. Abou-Taleb, K.A.A., Mashhoor, W.A., Nasr, S.A., Sharaf, M.S. and Abdel-Azeem, H.H.M (2009). Nutritional and environmental factors affecting cellulose production by two strains of cellulolytic bacilli. Australian Journal of Basic and Applied Sciences, 3:2429-2436.

3. Acharya, S. and Chaudhury, A (2012). Bioprospecting Thermophiles for Cellulase Production: A Review. Brazilian Journal of Microbiology, 2012:844-856.

4. Adsul, M.G., Ghule, J.E., Singh, R., Shaikh, H., Bastawdea, K.B., Gokhale, D.V. and Varma, A.J (2004). Polysaccharides from bagasse: applications in cellulase and xylanase production. Carbohydrate Polymer, 57:67-72

http://dx.doi.org/10.1016/j.carbpol.2004.04.001

5. Akinyele, B.J., Fabunmi, A.O. and Olaniyi OO (2013). Effect of variation in growth parameters on cellulases activity of Trichoderma viride NSPR006 cultured on different wooddusts. Malaysian Journal of Microbiology, 9(3):193-200.

6. Ali, S., Sayed, A., Sarker, R.T. and Alam, R (1991). Factors affecting cellulase production by Aspergillus terreus. World Journal of Microbiology and Biotechnology, 7:62-66.

7. Asgher, M., Ahmad, Z. and Iqbal, H.M.N (2013). Alkali and enzymatic delignification of sugarcane bagasse to expose cellulose polymers for saccharification and bioethanol production. Industrial Crops and Products, 44:488-495.

8. Azzaz, H.H., Murad, H.A., Kholif, A.M., Hanfy, M.A. and Abdel Gawad, M.H (2012). Optimization of Culture Conditions Affecting Fungal Cellulase Production. Research Journal of Microbiology, 7(9):23-31.

9. Bakare, M.K., Adewale, I.O Ajayi, A.O., Okoh, A.I and Shonukan, O.O (2005). Regulatory mutations affecting the synthesis of cellulase in Pseudomonas fluorescens. African Journal of Biotechnology, 4(8):838-843.

10. Balaraju, K., Park, K., Jahagirdar, S. and Kaviyarasan, V (2010). Production of cellulase and laccase enzymes by Oudemansiella radicata using agro wastes under solid state and submerged conditions. Research in Biotechnology, 1:2128

11. Bhat, M.K (2000). Cellulase and related enzymes in biotechnology. Biotechnology Advances, 18:355-383.

12. Blanch, H.W., Simmons, B.A. and Klein-Marcuschamer, D (2011). Biomass deconstruction to sugars. Biotechnology Journal, 6:1086-1102.

13. Bon, E.P.S. and Ferrara, M.A (2007). Bioethanol production via enzymatic hydrolysis of cellulosic biomass on "The role of agricultural biotechnologies for production of bioenergy in developing countries", FAO seminar, Rome.2007.

14. Brijwani, K., Oberoi, H.S. and Valdani, P.V (2010) Production of a cellulolytic enzyme system in mixed culture solid state fermentation of soybean hulls supplemented with wheat bran. Process Biochemistry, 45: 20-128.

15. Chandra, M.S., Viswanath, B. and Reddy, B.R (2007) Cellulolytic enzymes on lignocellulosic substrates in solid state fermentation by Aspergillus niger. Indian Journal of Microbiology, 17:323-328.

16. Chen, M., Xia, I. and Xue, P (2007). Enzymatic hydrolysis of corncob and ethanol production from cellulosic hydrolysate. International Journal of Biodeterioration and Biodegradation, 59:85-89.

17. Cosgrove, D.J (2005). Growth of the plant cell wall. Natural Review of Molecular and Celularl Biology, 6:850-861.

18. Devanathan, G., Shanmugan, A., Balasubramanian, T. and Manivannan, S (2007). Cellulase production by Aspergillus niger isolated from coastal mangrove debris. Trends in Applied Sciences Research, 2:23-27.

19. Eveleigh, D.E., Bok, J.D., El-Dorry, H.S., El-Gogary, S. Eliston, K., Goyal, A., Waldron, C., Wright, R. and Wu, Y.M (2005). Cellulase lessons revealed through the microbe's perspective. Applied Biochemistry and Biotechnology, 5152(0):169-177.

20. Fang, X., Yano, S., Inoue, H. and Sawayama, S (2009). Strain improvement of Acremonium cellulolyticum for cellulase production by mutation. Journal of Bioscience and Bioengineering, 107:256-261.

21. Gautam, S.P., Budela, P.S., Pandey, A.K., Jamaluddin, A.M.K. and Sarsaiya, S (2010). Optimization of the medium for the production of cellulase by Trichoderma viride using submerged fermentation. International Journal of Environmental Sciences, 1(4):656-665.

22. Ghose, T.K (1987). Measurement of cellulase activities. Pure and Applied Chemistry 59:257-268.

23. Gupta, R., Gigras, P., Mohapatra, H., Goswami, V.K. and Chauhan, B (2008). Microbial $\alpha$-amylases. A Biotechnological Perspective. Process Biochemistry, 38(11):1599-1616.

24. Hafiz, M.N.I., Muhammad, A., Ishtiaq, A. and Shahbaz, H (2010). Media optimization for hyperproduction of carboxymethyl cellulase using proximally analysed agroindustrial residues with Trichoderma harzianum under SSF. International Journal of Agriculture Science and Veterinary Medicine, 4(2):47-55.

25. Han, S.O., Yukawa, H., Inui, M. and Doi, R.H (2003) Regulation of expression of cellulosomal cellulase and hemicellulase genes in Clostridium cellulovorans. Journal of Bacteriology, 185:6067-6075.

26. Hikaru, N., Katsunori, O., Ryota K., Kubota, T., Onodera, T., Ochiai, N., Omata, N., Ogasawara, W., Okada, H. and Morikawa, Y (2008). Characterisation of the catalytic domain of Trichoderma reesei endo glucanase I, II and III expressed in Escerichia coli. Applied Microbiology and Biotechnology, 81:681-689.

27. Howell, J.A. and Mangat, M (1978). Enzymatic deactivation during cellulose hydrolysis. Biotechnology and Bioengineering, 20:847-863.

28. Iqbal, H.M.N., Kyazze, G. and Keshavarz, T (2013) Advances in valorization of lignocellulosic materials by biotechnology: An overview. BioResource, 8:3157-3176.

29. Irshad, M., Anwar, Z., But, H.I., Afroz, A., Ikram, N. and Rashid, U (2013). The industrial applicability of purified cellulase complex indigenously produced by Trichoderma viride through solid-state bio-processing of agro-industrial and municipal paper wastes. BioResource, 8:145-157.

30. Kathiresan, K. and Manivannan, S (2006). Cellulase production by Penicillium fellutanum isolated from coastal mangrove rhizosphere soil. Research Journal of Microbiology, 1(5):438-442.

31. Kim, S. and Dale, B.E (2004). Global potential bioethanol production from wasted crops and crop residues. Biomass and Bioenergy, 26(4):361-375.

32. Klein-Marcuschamer, D., Oleskowicz-Popiel, P., Simmons, B.A. and Blanch, H.W (2011). The challenge of enzyme costs in the production of lignocellulosic biofuels. Biotechnology and Bioengineering, 109(4):1083-1087. https//doi:10.1002/bit.24370.

33. Krishna, C. (1999). Production of bacterial cellulases by solid state bioprocessing of banana wastes. Bioresource Technology, 69(3):231-239.

34. Lee, R.L., Willem, H.V.Z., John, E.M. and Mark, L (2005). Consolidated bioprocessing of cellulosic biomass: an update. Current Opinion in Biotechnology, 16:577-583.

35. Liu, J. and Yang, J (2007). Cellulase production by Trichoderma koningi AS3.4262 in solid state fermentation using lignocellulosic waste from vinegar industry. Food Technology and Biotechnology, 45:420-425.

36. Lynd, L.R., Weimer, P.J. and Van Zyl, W.H (2002). Pretorius IS. Microbial Cellulase Utilisation: Fundamentals and 
Biotechnology. Microbiology and Molecular Biology Reviews, 66:506-577.

37. Mabrouk, E.M. and Ahwany, M.D (2008). Production of mannanase by Bacillus amyloliquifaciens 10A1 cultured on potato peels. African Journal of Biotechnology, 7(8):1128

38. Mandels, M. and Weber, J (1969). Exoglucanase activity by microorganisms. Advances in Chemistry, 95:391-414.

39. Milala, M.A., Shugaba, A., Gidado, A., Ene, A.C. and Wafar, J.A (2005). Studies on the use of agricultural wastes for cellulose enzyme production by Aspergillus niger. Research Journal of Agricultural and Biological Sciences, 1(4):325328.

40. Miller, G.L (1959). Use of dinitrosalicylic acid reagent for determination of reducing sugar. Analytical Chemistry, $31: 426-428$.

41. Mrudula, S. and Murugammal, R (2011). Production of cellulose by Aspergillus niger under submerged and solid state fermentation using coir waste as a substrate. Brazilian Journal of Microbiology, 42:1119-1127.

42. Mussato, S.I., Fernandes, M., Mancilha, I.M. and Roberto, I.C (2008). Effects of medium supplementation and $\mathrm{pH}$ control on lactic acid production from brewer's spent grain. Biochemical Engineering Journal, 40:437-444.

43. Narasimha, G., Sridevi, A., Buddola, V., Subhosh, C.M. and Rajasekhar, R.B (2006). Nutrient effects on production of cellulolytic enzymes by Aspergillus niger. African Journal of Biotechnology, 5:472-476.

44. Nascimento, R.P., Junior, N.A., Pereira, Jr. N., Bon, E.P.S. and Coelho, R.R.R (2009). Brewer's spent grain and corn steep liquor as substrates for cellulolytic enzymes production by Streptomyces malaysiensis. Letters in Applied Microbiology, 48:529-535.

45. Nipa, M.N., Sultana, S. and Hakim, M.A (2006). Induction of cellulose biosynthesis by cellobiose octaacetate in Aspergillus humicola. Microbiology Journal, 23:174-176.

46. Odeniyi, O.A., Onilude, A.A. and Ayodele, M.A (2009). Production characteristic and properties of cellulase/polygalacturonase by a Bacillus coagulans strain from a fermenting palm-fruit industrial residue. African Journal of Microbiology Research, 3(8):407-417.

47. Ogel, Z.B., Yarangumeli, K., Du, H. and Ifrij, J (2001). Submerged cultivation of Scytalidium thermophilum on complex lignocellulose biomass. Enzyme and Microbial Technology, 28:689-695.

48. Omojasola, P.F., Jilani, O.P. and Ibiyemi, S.A (2008). Cellulase Production by Some Fungi Cultured on Pineapple Waste. Nature and Science, 6(2):64-79.

49. Paengkoum, S., Wanapal, M. and Paengkoum, P (2013). Effects of pineapple peel and rice straw ratios as basal roughage in dairy cow. World Academy of Science, Engineering and Technology, 7(1):7-8.

50. Pham, T.H., Quyen, D.T. and Nghiem, N.M (2010). Optimization of endoglucanase production by Aspergillus niger VTCC-F021. Australian Journal of Basic and Applied Sciences, 4(9):4151-4157.

51. Rani, D.S. and Nand, K (2004). Ensilage of pineapple processing water for methane generation. Waste Management, 24:523-528.

52. Ravindran, C., Naveenan, T. and Varatharajan, G (2010) Optimization of alkaline cellulase production from marine derived fungi, Chaetomium sp., using agricultural and industrial wastes as substrates. Botanica Marina, 53(3):275282.

53. Reddy, G.P.K., Narasimha, G., Kumar, K.D., Ramanjaneyulu, G., Ramya, A., Shanti Kumari, B.S. and Reddy, B.R (2015). Cellulase production by Aspergillus niger on different lignocellulosic cubstrates. International Journal of Current Microbiology and Applied Science, 4(4):835-845.

54. Riswan, S.B.A., Muthuvelayudham, R. and Viruthagiri, T. 92012). Statistical optimization of nutrients for production cellulase \& hemicellulase from rice straw. Asian Journal of Biochemistry and Pharmaceutical Research, 2:154-174.

55. Rubin, E.M (2008). Genomics of cellulosic biofuels. Nature, 454(14):841-845.

56. Sarao, L.K., Arora, M. and Sehgal, V.K (2010). Use of Scopulariopsis acremonium for the production of cellulose and xylanase through submerged fermentation. African Journal of Biotechnology, 4(14):1506-1510.

57. Shoichi, T., Xoighi, K. and Hiroshi, S (1985). Cellulase production by Penicillium purpurogenum. Journal of Fermentation Technology, 62:127-127.

58. Singh, A (1999). Engineering enzyme properties. Indian Journal of Microbiology, 39(2):65-77.

59. Sonjoy, S.B., Bex, K. and Honston, H (1995). Cellulase activity of Trichoderma reesei (RUT-C30) on municipal solid waste. Applied Biochemistry and Biotechnology, 5152(1):145-153

60. Stojceska, V. and Ainsworth, P (2008). The effect of different enzymes on the quality of high-fibre enriched brewer's spent grain breads. Food Chemistry, 110:865-872.

61. Xavier, S. and Lonsane, B.K (1994). Factors influencing fungal degradation of total soluble carbohydrates in sugarcane-pressmud under solid state fermentation. Process Biochemistry, 16:435-440.

62. Xiros, C., Topakas, E., Katapodis, P. and Christakapoulos, P (2008). Evaluation of Fusarium oxysporium an enzyme factory for the hydrolysis of brewer's spent grain with improved biodegradability for ethanol production. Industrial Crops Production, 8:213-224.

63. Youssef, G.A. and Berekaa, M.M (2009). Improved production of endoglucanase enzyme by Aspergillus terreus; Application of Plackett-Burman design for optimization of process parameters. Biotechnology, 8(2):212-219. 